bacteriological effect of fosfomycin (FOM) on salmonella infections-effect of FOM on the phagocytic action of human leukocytes against salmonella, 12. International Congress of Chemotherapy, Florence, Italy, 1981, abstr 661

24. Traub WH 1983 Interactions of antimicrobial drugs and combined phagocytic/ serum bactericidal activity of defibrinated human blood against serratia marcescens. III. Beta-lactam-antibiotics and fosfomycin. Chemotherapy 29:48-57

25. Veale DR, Finch H, Smith H 1976 Penetration of penicillin into human phagocytes containing Neisseria gonorrhoeae: intracellular survival and growth at optimum concentrations of antibiotic. J Gen Microbiol 95: 353363
26. Weening RS, Kabel P, Pijman P, Roos D 1983 Continuous therapy with sulfamethoxazole-trimethoprim in patients with chronic granulomatous disease. J Pediatr 103:127-130

27. Welch WD, Davis D, Thrupp LD 1981 Effect of antimicrobial agents on human polymorphonuclear leukocyte microbicidal function. Antimicrob Agents Chemother 20:15-20

28. Woodruff HB, Mata JM, Hernández S, Mochales S, Rodriguez A, Stapley EO, Wallick H, Miller AK, Hendlin D 1977 Fosfomycin: laboratory studies. Chemotherapy 23(suppl 1):1-22

29. Yourtee EL, Root RK 1982 Antibiotic-neutrophil interactions in microbicida killing. In: Gallin JL, Fauci AS (eds) Advances in Host Defense Mechanisms, Vol I. Raven Press, New York, pp 187-209

\title{
Age-Related Red Cell Enzymes in Children with Transient Erythroblastopenia of Childhood and with Hemolytic Anemia
}

\author{
ERNEST BEUTLER AND GARY HARTMAN \\ Scripps Clinic and Research Foundation, Department of Basic and Clinical Research, La Jolla; and Children's \\ Hospital of San Diego, San Diego, California
}

\begin{abstract}
Red cell enzymes of three children with transient erythroblastopenia of childhood were measured and compared with those of age-matched normal children and children with hemolytic anemia. While the activity of "age-dependent" enzyme such as hexokinase, aldolase, glucose-6-phosphate dehydrogenase, glutamic-oxaloacetic transaminase, and pyruvate kinase were greatly increased in the red cells of children with hemolytic anemia, they were not decreased in the red cells of children with erythroblastopenia of childhood. Only the activity of pyrimidine $5^{\prime}$-nucleotidase was consistently low red cells of these chidren. These findings are inconsistent with the usual concept that red cell enzyme activities decline throughout red cell life span. Rather, they suggest that there may be very rapid loss in the activity of some red cell enzymes during the first few days of red cell life with little further decline in enzyme activity. (Pediatr Res 19: 44-47, 1985)
\end{abstract}

Transient erythroblastopenia of childhood is a relatively uncommon disorder of infants and young children. It is characterized by a profound but transient cessation of erythropoiesis followed within a few weeks or months by complete recovery (1).

We have recently had the opportunity to study red cell enzymes in three children with this relatively rare disorder and to compare

Received December 1, 1983; accepted July 23, 1984.

Correspondence Dr. Ernest Beutler, Scripps Clinic and Research Foundation, Department of Basic and Clinical Research, 10666 North Torrey Pines Road, La Jolla, CA 92037.

This work was funded in part by NIH Division of Heart, Lung and Blood Grant HL25552.

Publication 3136BCR from the Research Institute of Scripps Clinic and Research Foundation. the levels of red cell enzymes with those of children in the same age group who have hemolytic anemia. These investigations have provided us with some interesting new insights into the manner in which red cell enzyme activities, particularly that of pyrimidine-5'-nucleotidase, decline with increasing red cell age.

\section{PATIENTS}

M.R., born on January 7, 1982, of Mexican-American parents was first seen at 15 months of age. He had a history of an upper respiratory infection 2 months prior to being seen. This had been treated with aspirin and with antibiotics. His $\mathrm{Hb}$ was $5.6 \mathrm{~g} / 100$ $\mathrm{ml}$, hematocrit was $16.3 \%$, red count was 1.9 million $/ \mu \mathrm{l}$, white count was $6400 / \mu \mathrm{l}$ with a normal differential, and reticulocyte count was $0.2 \%$. Bone marrow aspiration revealed normal cellularity with only $8 \%$ total erythroid cells. A blood sample was drawn for enzyme assay. The pyrimidine $5^{\prime}$-nucleotidase activity was 36.7 units/g $\mathrm{Hb}$ (mean normal $\pm 1 \mathrm{SD}=138.8 \pm 18.91$ $\mathrm{mU} / \mathrm{g} \mathrm{Hb}$ ). The patient was given a single transfusion of $160 \mathrm{ml}$ of packed red cells. His reticulocyte count gradually rose and reached $1.3 \% 10$ wk after first being seen. At this time his $\mathrm{Hb}$ was $14.8 \mathrm{~g} / 100 \mathrm{ml}$, hematocrit of $43.8 \%$, and red count of 4.96 million.

C.H. was born on September 2, 1981. He was first seen at 19 months of age with a history of recurrent upper respiratory infection and diarrhea for the preceding 4-5 wk. His hematocrit had been found to be $23 \% 1$ wk earlier, and he had been placed on iron. His past history was significant only in that he had received exchange transfusions only because of $\mathrm{Rh}$ incompatibility.

The $\mathrm{Hb}$ was $7.4 \mathrm{~g} / 100 \mathrm{ml}$, hematocrit was $21.4 \%$, the white count was $10,300 \mu \mathrm{l}$, platelets were $344,000 \mu \mathrm{l}$, and the differential was normal. The reticulocyte count was recorded as $0 \%$. Bone marrow examination showed only $5 \%$ total erythroid cells. After blood was drawn for red cell enzyme assays. the patient 
was transfused. Pyrimidine $5^{\prime}$-nucleotidase activity was 19.2 $\mathrm{mU} / \mathrm{g} \mathrm{Hb}$. Two months later the $\mathrm{Hb}$ concentration of the blood was recorded at $12.5 \mathrm{~g} / 100 \mathrm{ml}$ and the reticulocyte count at $0.7 \%$.

S.A. was born on July 18, 1981. At age 23 months an upper respiratory infection was noted and the $\mathrm{Hb}$ was found to be 7.2 $\mathrm{g} / 100 \mathrm{ml}$ with a hematocrit of 24 and a reticulocyte count of $0.5 \%$. Oral iron therapy was given for $1 \mathrm{wk}$, after which the $\mathrm{Hb}$ had declined to $6.6 \mathrm{~g} / 100 \mathrm{ml}$ with a hematocrit of $20.5 \%$ and a reticulocyte count of $0.3 \%$. Bone marrow examination showed the presence of only $9 \%$ erythroid cells. Pyrimidine 5 '-nucleotidase was $48.4 \mathrm{mU} / \mathrm{g} \mathrm{Hb}$. After blood was drawn for red cell enzyme assays the child was transfused with $190 \mathrm{ml}$ of packed red cells. Three weeks later the $\mathrm{Hb}$ was $12.4 \mathrm{~g} / 100 \mathrm{ml}$, hematocrit was $39.2 \%$, red count was $4.53 \times 10^{6} / \mu \mathrm{l}$, and reticulocytes were $0.9 \%$.

\section{MATERIALS AND METHODS}

Blood samples were examined from the three children with transient erythroblastopenia of childhood, from nine children aged 1-2 yr with hemolytic anemia with reticulocyte counts ranging from $5.4-22 \%$ and seven healthy children aged $1-5 \mathrm{yr}$. The latter samples were obtained in the course of drawing routine preoperative samples in preparation for elective surgery.

The activities of red cell enzymes except for that of pyrimidine-
5 -nucleotidase were measured using previously described spectrophotometric methods (2). The activity of the latter enzyme was estimated radiometrically (3). The UV spectra of perchloric acid extracts of red cells were examined spectrophotometrically to determine whether increased levels of pyrimidine nucleotides were present $(4,5)$.

\section{RESULTS}

The results of enzyme assays carried out on the red cells of the three patients at the time of erythroblastopenia and patients with hemolytic anemia are summarized in Figure 1. The decrease in the activity of pyrimidine- 5 '-nucleotidase is striking in each case of transient erythroblastopenia of childhood. Examination of perchloric acid extracts of the red cells failed, however, to demonstrate any increase in the level of pyrimidine nucleotides. In contrast to pyrimidine-5'-nucleotidase, the activities of other "age-dependent" enzymes such as hexokinase, aldolase, glucose6-phosphate dehydrogenase, and glutamic-oxaloacetic transaminase were normal or, in some cases, even slightly increased.

In the patients with hemolytic anemia, also summarized in Figure 1, there was a striking increase in the activity of pyrimidine $-5^{\prime}$-nucleotidase and also of the age-related enzymes, activities of which had been normal in the children with transient erythroblastopenia of childhood.

Table 1 summarizes the pyrimidine- $5^{\prime}$-nucleotidase activities

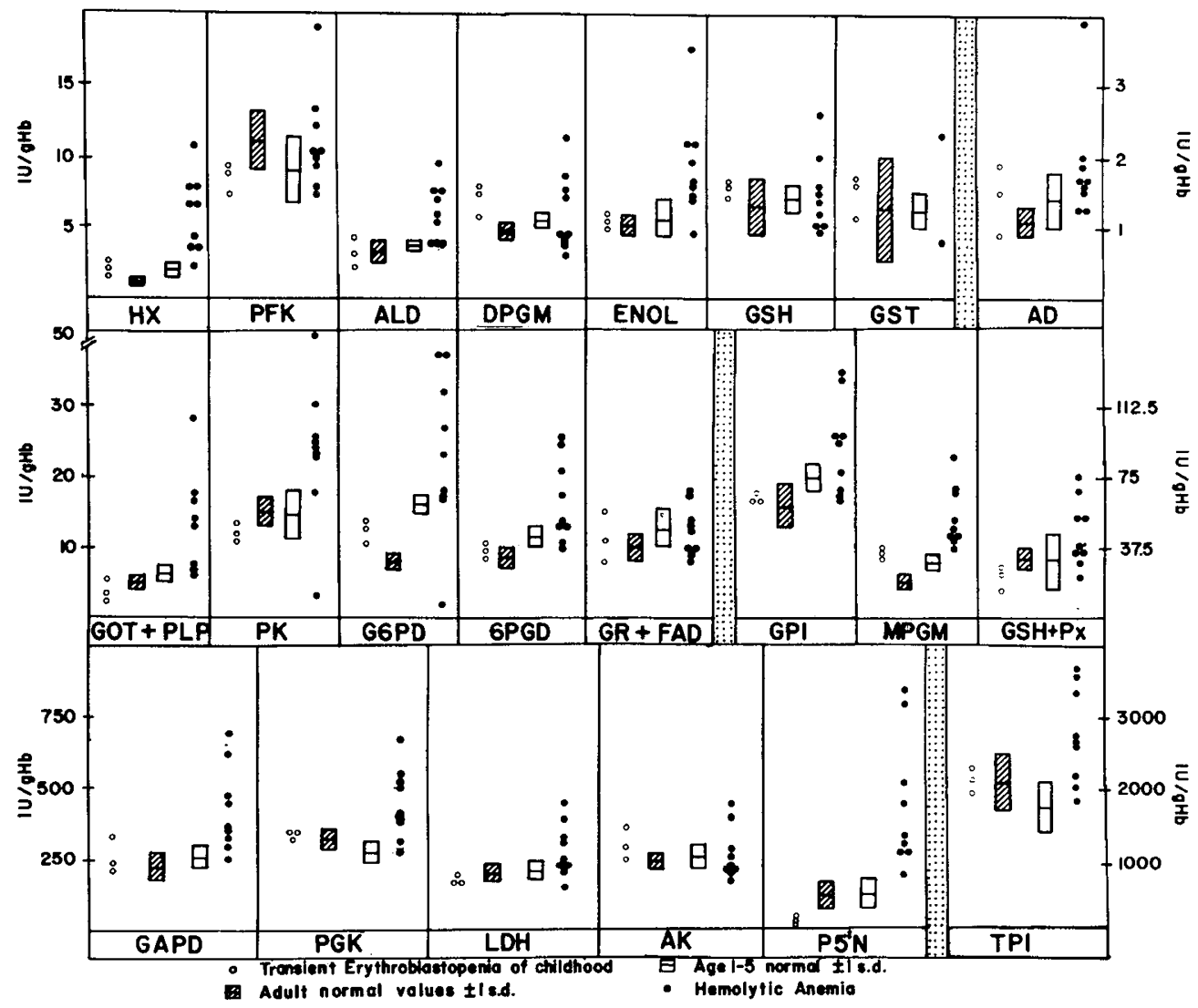

Fig. 1. Red cell enzyme activities in three patients with transient erythroblastopenia of childhood and nine children, age 1-2 yr, with hemolytic anemia. These activities are compared with normal values (bars) obtained from 20 adults and from seven chidren, aged 1-5 yr. The bars represent the mean $\pm 1 \mathrm{SD}$.

The following abbreviations are used. HX, hexokinase; PFK, phosphofructokinase; ALD, aldolase; DPGM, diphosphoglyceromutase; ENOL, enolase; GSH, reduced glutathione; GST, glutathione-S-transferase; AD, adenosine deaminase; GOT + PLP glutamic oxaloacetic transaminase assayed in the presence of an excess of pyridoxal-5-phosphate; PK, pyruvate kinase; G-6-PD, glucose 6-phosphate dehydrogenase; 6PGD, 6phosphogluconic dehydrogenase; GR + FAD, glutathione reductase assayed in an excess of flavin adenine dinucleotide; GPI, glucose phosphate isomerase; MPGM, monophosphate glyceratemutase; GSH + Px, glutathione peroxidase; GAPD, glyceraldehyde phosphate dehydrogenase; PGK, phosphoglycerate kinase; LDH, lactate dehydrogenase; AK, adenylate kinase; P5'-N, pyrimidine $5^{\prime}$-nucleotidase; TPI, triose phosphate isomerase. Units of pyrimidine $5^{\prime}$-nucleotidase represent nmol of CMP dephosphorylated per min and for all other enzymes $\mu$ mol of substrate consumed per $\min$ at $37^{\circ} \mathrm{C}$. In the case of GSH the units are $\mu \mathrm{mol} / \mathrm{g} \mathrm{Hb}$. 
Table 1. Pyrimidine-5'-nucleotidase $\left(P-5^{\prime}-N\right)$ activity

\begin{tabular}{cc}
\hline Patient & $\begin{array}{c}\text { P-5'-N } \\
\text { (unit/g Hb) }\end{array}$ \\
\hline C.H. & 100.50 \\
Mother & 102.40 \\
Father & 141.30 \\
M.R. & 141.85 \\
Mother & 157.64 \\
Father & 141.84 \\
Control & 188.60 \\
\hline
\end{tabular}

Normal Values $=138.3 \pm 18.91 \mathrm{U} / \mathrm{g} \mathrm{Hb}(1 \mathrm{SD})$.

Assays performed in patient C.H. and M.R. 3 months after original diagnosis of erythroblastopenia of childhood was established. The assay values of both parents of C.H. and M.R. are given. One unit represents $1 \mathrm{nmol} \mathrm{CMP}$ dephosphorylated per min at $37^{\circ} \mathrm{C}$.

of the red cells of parents of two of the patients and of these patients 3 months after original diagnosis. The normal values that were documented rule out hereditary pyrimidine- 5 '-nucleotidase deficiency as a cause of decreased enzyme activity in the children. Moreover, examination of the red cells of C.H. and M.R. about 3 months after initial examination revealed that the pyrimidine- 5 '-nucleotidase activity had returned to normal.

\section{DISCUSSION}

The markedly elevated activities of age-related enzymes such as hexokinase, aldolase, glucose-6-phosphate dehydrogenase, oxaloacetic transaminase, and pyruvate kinase confirms the wellknown relationship between red cell age and the activities of these enzymes. It was surprising then to find the activity of these enzymes to be unaffected in our patients with transient erythroblastopenia of childhood, while there was a striking decrease in the level of pyrimidine- $5^{\prime}$-nucleotidase. In an earlier publication we reported the findings in a $191 / 2$-month-old child with pyrimidine-5'-nucleotidase deficiency (6). This patient appeared to be quite different from the other patients in that the residual enzyme activity was somewhat higher, the reticulocyte count was only $2.0 \%$, basophilic stippling was absent from the red cells, and the activity of the red cells of his parents were borderline or normal. Follow-up of this child revealed that there had been complete hematological recovery (P. Singh, personal communication) and in the light of our findings in the three children described herein, we must conclude that this patient actually was in the early recovery phase of transient erythroblastopenia of childhood. In addition to the patients presented here we have examined the red cells of two other patients apparently recovering from transient erythroblastopenia of childhood. These patients, too, had an abnormally low red cell pyrimidine $5^{\prime}$-nucleotidase activity but normal activities of all other "age-related" enzymes.

Wang and Mentzer (7) estimated the levels of red cell enzymes in transient erythroblastopenia of childhood and found no significant decrease in hexokinase and pyruvate kinase activities and only borderline decreases in the activities of aldolase and glucose-6-phosphate dehydrogenase. Of the age-dependent red cell enzymes, they were able to document a significant decrease only in glutamic-oxaloacetic transaminase. In our patients, even the latter enzyme activity was within the normal range in two of the three patients.

These anomalous findings prompt us to reconsider the timedependent manner in which the decline of red cell enzymes occurs. One potentially powerful technique for measuring decline of enzyme activities during red cell life span is that employed by Löhr and Waller (8). Type $O$ red cells were transfused into type A recipient and activities of a number of enzymes were measured after recovering the red cells by differential agglutination. Unfortunately, serious errors may be introduced by the fact that cell fractions obtained in this way are invariably relatively heavily contaminated by recipient unagglutinated cells.
Most studies of the aging of red cells have been less direct. They have consisted of separating red cells into fractions enriched with young cells or old cells employing density gradients (9-11) or osmotic fragility (12) and relating various biochemical parameters to the relative age of the cell fraction obtained. The most sophisticated analysis of the decline of enzyme activities during red cell aging using such data is that employed by Piomelli and his colleagues $(9,13)$ in which red cells are separated by density. The logarithm of the enzyme activity of each fraction is then plotted against the probit of the cumulative fraction of the erythrocytes in the density fraction being examined. Piomelli et al. (9) and Seaman et al. (13) fitted a straight line to the data using the method of least squares to the data, and took the slope as the half-life of the enzyme. Using essentially the same transient erythroblastopenia of childhood Turner et al. (10) suggested that two exponentials fit data obtained with purine nucleoside phosphorylase and 6-phosphogluconate dehydrogenase better than did a single exponential. Indeed, either method of curve-fitting seems to be somewhat arbitrary. Moreover, the putative life span of red cells derived by this method actually depends on the assumption that density provides perfect separation of the red cells by age. It is clear that the slope of the curve obtained depends on this assumption from the following limiting consideration: if the density fractionation did not separate cells by age at all, the slope of the curve would be zero (all of the fractions would have the same enzyme activity). As the efficiency of the fractionation improved the curve would assume a slope, and this slope would increase until the efficiency of fractionation reached the theoretical optimum, viz. that all of the cells in each more dense fraction are older than all of the cells in the preceding less dense fraction. It is obvious that such separation is not approached by density gradients, since some reticulocytes are present even in the most dense fractions $(9,10)$. Indeed, applying this method to the aging of reticulocytes would provide a putative half-life of reticulocytes, which are well known to have a finite life span, and would therefore predict that some erythroid cells were still reticulocytes even after 100 or more days in the circulation.

The striking decline in pyrimidine- $5^{\prime}$-nucleotidase activity of the red cells of patients with transient erythroblastopenia of childhood provides an interesting insight into the rate of decline of this enzyme with aging. It is most consistent with a very rapid loss of pyrimidine- 5 '-nucleotidase activity with the early maturation of red cells. Since the activity of this enzyme is probably only required for the depolymerization of RNA in the reticulocyte, rapid loss of this enzyme early in red cell maturation would not deprive the erythrocyte of a needed function. In contrast, enzymes such as hexokinase and aldolase, on the mainstream of glycolysis, are required for normal metabolism throughout the red cell life span. Indeed, reticulocytes possess an ATP-dependent protease which is no longer present in mature erythrocytes. It is entirely possible that this enzyme system, thought to function to remove mitochondria in the maturing erythroid cell (14), may also remove pyrimidine- 5 '-nucleotidase.

Our studies of patients with transient erythroblastopenia of childhood suggest that age-related enzymes such as hexokinase which are useful in defining young red cell populations cannot reliably identify aged populations of erythrocytes. This suggestion is based on the assumption that the red cells of patients with erythroblastopenia of childhood represent an aged erythrocyte population. If, on the other hand, red cell life span in this disorder is decreased, it is possible that the normal level of such agerelated enzymes we have observed represents a balance between a lack of the very youngest cells and the relatively age-skewed population of the remaining cells. While the same objection may be made to data derived from other patients with aplasia, we have encountered the identical phenomenon in transfusiondependent adult patients with idiopathic bone marrow failure or bone marrow failure induced iatrogenically in the course of bone marrow transplantation (15). If the red cells of patients with 
erythroblastopenia of childhood are, indeed, an aged population our findings are inconsistent with a steady exponential decay in the activity of enzymes such as hexokinase and suggest that a rapid loss of enzyme from reticulocytes is followed by relatively little further decline in enzyme activity during the remainder of the red cell life span. Pyrimidine-5'-nucleotidase activity, in contrast, seems to be very largely lost in the first few days of red cell life.

\section{REFERENCES}

1. Labotka RJ, Maurer HS, Honig GR 1981 Transient erythroblastopenia of childhood. Am J Dis Child 135:937-940

2. Beutler E 1975 Red Cell Metabolism. A Manual of Biochemical Methods, 2nd ed. Grune \& Stratton, New York

3. Torrance J, West C, Beutler E 1977 A simple rapid radiometric assay for pyrimidine-5'-nucleotidase. J Lab Clin Med 90:563-568

4. Beutler E 1983 Detection of pyrimidine nucleotides. In: Williams WJ, Beutler E, Erslev AJ, Lichtman MA (ed) Hematology, 3rd ed. McGraw-Hill, Inc., New York, p 1644

5. Valentine WN, Fink K, Paglia DE, Harris SR, Adams WS 1974 Hereditary hemolytic anemia with human erythrocyte pyrimidine 5 '-nucleotidase deficieny. J Clin Invest 54:866-879
6. Beutler E, Baranko PV, Feagler J, Matsumoto F, Miro-Quesada M, Selby G, Singh P 1980 Hemolytic anemia due to pyrimidine-5'-nucleotidase deficiency: Report of eight cases in six families. Blood 56:251-255

7. Wang WC, Mentzer WC 1976 Differentiation of transient erythroblastopenia of childhood from congenital hypoplastic anemia. J Pediatr 88:784-789

8. Löhr GW, Waller HD 1959 Zellstoffwechsel und zellalterung. Klin Wochenschr 37:833-843

9. Piomelli S, Corash LM, Davenport DD, Miraglia J, Amorosi EL 1968 In vivo lability of glucose-6-phosphate dehydrogenase in GdA- and GD-Mediterranean deficiency. $J$ Clin Invest 47:940-948

10. Turner BM, Fisher RA, Harris H 1974 The age related loss of activity of four enzymes in the human erythrocyte. Clin Chim Acta 50:85-95

11. Syllm-Rapoport I, Daniel A, Starck H, Hartwig A, Gross J 1981 Creatine in density-fractionated red cells, a useful indicator of erythropoietic dynamics and of hypoxia past and present. Acta Haematol 66:86-95

12. Bartos HR, Desforges JF 1967 Enzymes as erythrocyte age reference standards. Am J Med Sci 254:862-865

13. Seaman C, Wyss S, Piomelli S 1980 The decline in energetic metabolism with aging of the erythrocyte and its relationship to cell death. Am J Hematol 3:31-42

14. Muller M, Dubiel W, Rathmann J, Rapoport S 1980 Determination and characteristics of energy-dependent proteolysis in rabbit reticulocytes. Eur $\mathbf{J}$ Biochem 109:405-410

15. Beutler E 1985 Biphasic loss of red cell enzyme activity during in vivo aging. In: Eaton JW, White JG (ed) Cellular and Molecular Aspects of Aging: The Red Cell as a Model. Alan R. Liss, Inc., New York, NY

\title{
Plasma and Urinary Catecholamines in Patients with Cystic Fibrosis
}

\author{
MARTIN H. SCHÖNI, KURT TÜRLER, HANS KÄSER, AND RICHARD KRAEMER
}

Institute for Clinical and Experimental Cancer Research [M.H.S., K.T., H.K.] and Department of Pediatrics

[R.K.], University of Berne, Switzerland

\begin{abstract}
In 43 patients with cystic fibrosis (age 8-23 yr, 26 boys and 17 girls) attending a summer camp in a mountain rehabilitation center and in 25 parents (heterozygotes) plasma epinephrine, norepinephrine, dopamine and plasma activity of dopamine- $\beta$-hydroxylase were determined as well as the 24-h excretion of the free urinary amines (epinephrine, norepinephrine, dopamine), their $O$ methylated products (metanephrine, normetanephrine, 3methoxytyramine) and the urinary phenolic acids (vanilmandelic and homovanillic). Also the metabolic breakdown product of serotonin in urine, the 5-hydroxyindoleacetic acid, was determined. Significantly elevated plasma dopamine (0.03-0.45 nmol/liter for controls versus 1.70-2.21 nmol/liter for cystic fibrosis) and slightly higher plasma norepinephrine levels were found in patients with cystic fibrosis. An increased 5-hydroxyindoleacetic acid excretion was noticed in adolescent patients which correlated with the disease state and the extent of lung involvement. No abnormalities of plasma amine levels were seen in the parents of the patients. Despite controversial results, CF patients seem to have an alteration in catecholamine me-
\end{abstract}

Received March 15, 1984, accepted July 24, 1984.

Reprint address R. Kraemer, M.D., Department of Pediatrics, University of Berne, Inselspital, $\mathrm{CH}-3010$ Berne, Switzerland.

The study was supported in part by the Swiss National Foundation for Scientific Research. M. H. Schöni is a recipient of a Research Grant from the same institution to conduct cystic fibrosis research in Vancouver, Canada. tabolism which is reflected in higher plasma dopamine levels. (Pediatr Res 19: 47-52, 1985)

\section{Abbreviations}

$\mathrm{CF}$, cystic fibrosis

$\mathrm{HZ}$, heterozygotes

$E$, epinephrine

NE, norepinephrine

DA, Dopamine

DBH, dopamine- $\beta$-hydroxylase

DOPA, 3,4-dihydroxyphenylalanine

DOPAC, 3,4-dihydroxyphenylacetic acid

MN, metanephrine

NM, normetanephrine

3-MT, 3-Methoxytyramine

VMA, vanilmandelic acid

HVA, homovanillic acid

5-HIAA, 5-hydroxyindoleacetic acid

COMT, catechol- $O$-methyltransferase

MAO, monoaminooxidase

Two earlier reports described elevated free urinary catecholamines (2) and adrenal medullary hyperplasia (3) in patients 